Вип. 1, 2019

УДК 621.316.925

А. В. Чабан

Львівський національний аграрний університет, кафедра електротехнічних систем, atchaban@gmail.com,

Г. М. Лисяк Національний університет “Львівська політехніка", кафедра електроенергетики та систем управління, gmlysiak@gmail.com

В. Р. Левонюк

Львівський національний аграрний університет, кафедра електротехнічних систем, gmlysiak@gmail.com

\title{
МАТЕМАТИЧНЕ МОДЕЛЮВАННЯ КОМУТАЦЙНИХ ЕЛЕКТРОМАГНІТНИХ ПРОЦЕСІВ У ДОВГИХ ЛІНІЯХ ЕЛЕКТРОПЕРЕДАЧ У ЦИКЛІ АПВ
}

https://doi.org/10.23939/sepes2019.01.063

(C) Чабан А. В., Лисяк Г. М., Левонюк В. Р., 2019

Виконано аналіз наукових публікацій, який показав, що здебільшого дослідження комутаційних перехідних процесів в електричних мережах під час циклів автоматичного повторного ввімкнення (АПВ) вимикачів здійснюють без урахування впливу на них електромеханічних процесів у механізмах переміщення контактів вимикачів, незважаючи на те, що швидкість їх перебігу співмірна 3 швидкістю проходження електромагнітних процесів. На основі модифікованого принципу Гамільтона - Остроградського запропоновано математичну модель фрагмента електричної мережі, який складається із міжсистемної лінії електропередачі надвисокої напруги, компенсувальних реакторів та високовольтного вимикача з пристроєм АПВ.

Показано, що запропонована в роботі методика ідентифікації крайових умов другого роду до диференціального рівняння довгої лінії підвищус ефективність побудови їі моделі, оскільки не потребус створення розширених колових заступних схем, 3 одного боку; та дає змогу на польовому рівні врахувати перебіг електромагнітних процесів, 3 другого. Використана в роботі математична модель вимикача надвисокої напруги дає змогу враховувати комутаційні дугові процеси на основі нелінійного активного опору і смності та динаміку руху механізму переміщення контактів на основі 
теорії Лагранжа. Це уможливлює ефективне дослідження перехідних процесів у електричних мережах під час АПВ вимикачів без застосування процедури пошуку початкових умов комутації.

На підгрунті розробленої математичної моделі написано програмний код алгоритмічною мовою Visual Fortran та здійснено комп'ютерну симуляцію перехідних комутаційних процесів у довгій лінії електропередачі з урахуванням дії пристрою однократного АПВ та механічних процесів у вимикачі. Результати досліджень подано у вигляді рисунків, які проаналізовано.

Підтверджено, що розвиток і застосування міждисциплінарних (інтердисциплінарних) методів дослідження дає змогу виключно з використанням сдиного енергетичного підходу будувати моделі електротехнічних та електромеханічних підсистем як елементів сдиної електроенергетичної системи, зокрема й математичні моделі вимикачів надвисокої напруги та довгих ліній електропередач.

Ключові слова: математичне моделювання; комутаційні процеси; принцип Гамільтона-Остроградського; електрична мережа; високовольтний вимикач; автоматичне повторне ввімкнення.

\section{Постановка проблеми}

Автоматичне повторне ввімкнення (АПВ) ліній електропередач надвисокої напруги є одним із ефективних способів підвищення надійності функціонування електроенергосистем та електропостачання споживачів [1]. Дослідження циклів АПВ здійснюється за допомогою спеціалізованих технічних програм із використанням вимірювальних засобів, що дають важливу інформацію про перехідні процеси у лінії. Проте проводити такі дослідження доволі дорого, тому процедура математичного моделювання згаданих процесів домінує під час таких досліджень. Окрім цього, варто звертати увагу на рівень адекватності моделювання комутацій, оскільки під час останніх у вимикачах виникає і згасає дуга між їх контактами. Загальноприйняті допущення стосовно моделювання вимкнення струму вимикачами виключно за нульового його значення не завжди відображають реальні фізичні явища на достатньому рівні адекватності. Однак опис процесу розриву струму за ненульового його значення у момент розмикання контактів вимикача спричиняє проблему пошуку початкових умов комутацій. При цьому зазвичай не враховують вплив механічних процесів у пристроях переміщення контактів вимикачів на електромагнітні процеси, зважаючи на те, що швидкість їх перебігу співмірна [2].

Відомо, що для адекватного опису дугових процесів у вимикачі необхідно задіяти складний апарат прикладної фізики, зокрема, теорію електромагнітного поля, рівняння нестаціонарної термодинаміки Фур'є, теорію плазми, а також теорію Лагранжа для опису переміщення контактів вимикача [3]. Такі моделі вимикачів якщо й побудовані, то сьогодні $є$ надзвичайно складними й громіздкими, а тому не завжди прийнятні для задач аналізу комутаційних процесів у довгих лініях електропередач. Отже, побудова ефективних, достатньо адекватних та одночасно порівняно простих моделей для дослідження комутаційних перехідних процесів у елементах електричних мереж $є$ актуальним завданням.

\section{Аналіз останніх досліджень}

Сьогодні чимало науковців досліджують перехідні комутаційні процеси, які відбуваються в елементах електричних мереж. Ми ж розглянемо лише деякі основні праці, дотичні до наших досліджень.

У статті [4] досліджено перехідні електромагнітні процеси під час роботи АПВ у компенсованих лініях електропередач напругою 500-1150 кВ, а комутації здійснюються за допомогою елегазових вимикачів. У роботі [5] здійснено аналіз впливу перехідних процесів під час комутацій у 
лініях електропередач на експлуатаційний стан енергосистеми. У праці [6] досліджено перехідні процеси в лінії електропередачі із шунтувальними реакторами під час аварійного вимкнення лінії після короткого замикання. Тут практичну реалізацію досліджень проведено в програмному комплексі $E M T P-R V$. Автори роботи [7] досліджують перехідні індуктивні струми, викликані контрольованою та неконтрольованою комутаціями у високовольтних вимикачах, які зумовлені наявністю шунтових реакторів у системі; а також ввімкнення, вимкнення та АПВ лінії електропередачі 400 кВ. У праці [8] автори здійснили дослідження перехідних процесів у фрагменті електричної мережі під час роботи АПВ за допомогою програмного комплексу Matlab/Simulink.

Аналізуючи огляд доступної літератури, можна стверджувати, що дослідженням комутаційних перехідних процесів у лініях електропередач надвисокої напруги під час АПВ (урахування розривів першого роду функцій струму) приділено недостатньо уваги. Натомість достатньо добре вивчено згадані процеси за умови розриву функції струму виключно в нулі. Зокрема, розроблено низку нових прикладних програмних комплексів та розширено наявні: $M A E S$ (праця [4]), EMTP-RV (праці [5, 6, 7]), MatLab (праця [8]) та ін.

\section{Формування цілей статті}

Мета роботи - удосконалення методів та засобів аналізу комутаційних перехідних процесів у довгих лініях електропередачі з урахуванням дії пристрою однократного АПВ та механічних процесів у вимикачі.

\section{Виклад основного матеріалу}

Загальновідомо, що для повноцінного відтворення під час несиметричних збурень перехідних процесів у довгих лініях електропередач трифазного змінного струму за допомогою апарату математичного моделювання їх моделі необхідно формувати у трифазному виконанні. Однак на певних етапах удосконалення методів та засобів аналізу комутаційних перехідних процесів, зокрема під час апробації адекватності моделей комутаційних апаратів, у яких враховуються також їх механічні процеси, вважаємо за можливе проводити відповідні дослідження на основі математичних моделей тестових розрахункових схем заміщення в однолінійному виконанні. 3 метою максимального наближення одержуваних результатів до координат режимів реальних об'єктів електричних мереж використовуватимемо значення параметрів реальних об'єктів для складових фазних координат режиму прямої послідовності.

На рис. 1 репрезентовано розрахункову заступну схему фрагмента електричної мережі 750 кВ, який складається із міжсистемної лінії електропередачі надвисокої напруги, компенсувальних реакторів та високовольтного вимикача. Електроенергетичні системи 1 і 2 представлені їх еквівалентними електрорушійними силами, внутрішніми активними опорами та індуктивностями. Лінія електропередачі розглядається як лінія із розподіленими параметрами. Вимкнення струмів КЗ під час циклу АПВ здійснюватиметься вимикачем 750 кВ, електрична заступна схема якого має вигляд паралельно з'єднаних еквівалентних нелінійного активного опору та ємності (рис. 1) [9].

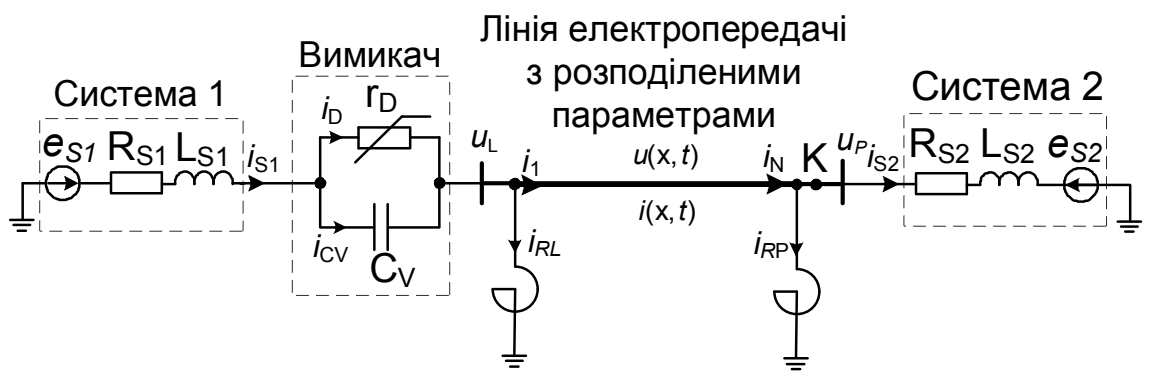

Рис. 1. Розрахункова заступна схема досліджуваного фрагмента електричної мережі 
Ми вже згадували, що врахування дугових процесів під час комутації у вимикачі надвисокої напруги є складним завданням. Багато науковців нехтує цими процесами, а комутацію здійснюють, замінюючи вимикач активним опором, і в момент, коли струм проходить через нуль, присвоюють цьому опору нескінченно велике значення. Ми ж пропонуємо враховувати ці процеси за допомогою активних опорів із нелінійними характеристиками, із урахуванням праці [10].

Досліджуваним комутаційним пристроєм ми вибрали елегазовий вимикач надвисокої напруги фірми $A B B$ типу $L T B \quad 362-800$ (T) $E 4$, який широко використовується не лише в електроенергетичних системах України, а й поза ії межами. Кожна фаза вимикача складається із двох послідовно з'єднаних між собою модулів. А кожен із модулів має по дві пари послідовно з'єднаних контактів, паралельно до кожної з яких під'єднано конденсатори для рівномірного розподілу напруги. За умови однакових нелінійних характеристик активних опорів та однакових значень ємностей параметри еквівалентних елементів електричної заступної схеми вимикача на рис. 1 матимуть такі значення: $r_{D}=4 r_{D R}, C_{V}=C_{V R} / 4$, де $r_{D R}$ - опір одного дугового проміжку; $C_{V R}-\epsilon$ мність конденсатора, увімкненого паралельно до однієї пари контактів вимикача.

Значення згаданого еквівалентного нелінійного опору $r_{D}$ залежатиме від відстані між контактами вимикача, яка, своєю чергою, залежатиме від швидкості їх розходження. Для урахування механічних процесів у вимикачі під час комутацій застосуємо математичну модель механізму переміщення контактів згаданого вимикача [9].

Оскільки в роботі досліджуватимуться процеси як у механічних, так і в електромагнітних підсистемах, це дає нам підстави використати варіаційні підходи. Зокрема, для аналізу перехідних процесів у фрагменті електричної мережі, зображеної на рис. 1, використаємо модифікований принцип Гамільтона - Остроградського [11]. Такий підхід дає змогу одержати вихідні рівняння стану тільки за допомогою єдиного енергетичного підходу, побудувавши розширену функцію Лагранжа [11].

Для досліджуваної системи розширений функціонал дії за Гамільтоном - Остроградським виглядатиме так [11]:

$$
S=\int_{0}^{t_{1}} L^{*} d t+\int_{0}^{t_{1}} \int_{l} L_{l} d l d t, I=\int_{l} L_{l} d l,
$$

де $S$ - дія за Гамільтоном-Остроградським; $L^{*}$ - розширена функція Лагранжа; $L_{l}-$ лінійна густина модифікованої функції Лагранжа; $I-$ енергетичний функціонал.

Розширена функція Лагранжа виглядає так [11]:

$$
L^{*}=\tilde{T}^{*}-P^{*}+\Phi^{*}-D^{*}, \quad L_{l}=\tilde{T}_{l}-P_{l}+\Phi_{l}-D_{l},
$$

де $L^{*}$ - розширена функція Лагранжа; $\widetilde{T}^{*}$ - кінетична коенергія; $P^{*}$ - потенціальна енергія; $\Phi^{*}-$ енергія дисипації; $D^{*}$ - енергія сторонніх непотенціальних сил; індекс $l$ позначає густини відповідних енергії (стосується складників розширеної функції Лагранжа для лінії електропередачі, оскільки вона розглядається як система із розподіленими параметрами).

Задля зменшення обсягу статті не наводимо виведення рівнянь. Ознайомитися з методикою отримання рівнянь такого плану можна в наших працях, наприклад, у [12]. Отже, запишемо кінцеві рівняння Ейлера-Лагранжа:

$$
\begin{gathered}
\frac{d i_{S 1}}{d t}=\frac{1}{L_{S 1}}\left(e_{S 1}-R_{S 1} i_{S 1}-u_{V}-u_{L}\right), \quad \frac{d i_{S 2}}{d t}=\frac{1}{L_{S 2}}\left(u_{P}-R_{S 2} i_{S 2}-e_{S 2}\right), \quad \frac{d u_{V}}{d t}=\frac{1}{C_{V}}\left(i_{S 1}-\frac{u_{V}}{r_{D}}\right) ; \\
\frac{d i_{R L}}{d t}=\frac{1}{L_{R L}}\left(u_{L}-R_{R L} i_{R L}\right), \frac{d i_{R P}}{d t}=\frac{1}{L_{R P}}\left(u_{P}-R_{R P} i_{R P}\right), \\
\frac{\partial v}{\partial t}=\left(C_{0} L_{0}\right)^{-1}\left(\frac{\partial^{2} u}{\partial x^{2}}-\left(g_{0} L_{0}+C_{0} R_{0}\right) v-g_{0} R_{0} u\right), \quad \frac{\partial u}{\partial t}=v ;
\end{gathered}
$$


Математичне моделювання комутаційних електромагнітних процесів у довгих лініях електропередач ...

$$
\frac{d V_{x}}{d t}=\frac{k \Delta x_{P}+4 F_{X}+k_{d} V_{x}}{m}, \quad \frac{d \Delta x_{P}}{d t}=V_{x}
$$

де $L_{S 1}, L_{S 2}$ - індуктивності систем 1 та $2 ; R_{S 1}, R_{S 2}$ - активні опори систем 1 та $2 ; e_{S 1}, e_{S 2}$ - електрорушійні сили систем 1 та 2; $C_{V}$ - ємність еквівалентного конденсатора, який увімкнений паралельно до еквівалентного розриву контактів вимикача; $i_{S 1}, i_{S 2}$ - струми систем 1 та $2 ; r_{D}$ - опір еквівалентної дуги вимикача; $\Delta x_{P}$ - переміщення пружини вимикача; $V_{x}$ - швидкість переміщення пружини вимикача; $k$ - коефіцієнт пружності пружини вимикача; $k_{d}$ - коефіцієнт дисипації вимикача; $m$ - приведена маса контактів; $F_{X}$ - виштовхувальна сила дуги однієї пари контактів вимикача, зведена до системи координат руху пружини, $u_{L}$ - напруга на початку лінії (з боку вимикача); $u_{P}-$ напруга в кінці лінії (з боку системи 2).

Третє рівняння у (4) (рівняння довгої лініі) доповнюємо крайовими умовами другого роду - рівнянням, яке записане за другим законом Кірхгофа для електричних кіл із розподіленими параметрами:

$$
-\frac{\partial u(x, t)}{\partial x}=R_{0} i(x, t)+L_{0} \frac{\partial i(x, t)}{\partial t} .
$$

Дискретизуючи третє і четверте рівняння в (4) та рівняння (6) за методом скінченних різниць (використовуючи поняття центральної похідної), отримаємо:

$$
\begin{gathered}
\frac{d v_{j}}{d t}=\left(C_{0} L_{0}\right)^{-1}\left(\frac{u_{j-1}-2 u_{j}+u_{j+1}}{(\Delta x)^{2}}-\left(g_{0} L_{0}+C_{0} R_{0}\right) v_{j}-g_{0} R_{0} u_{j}\right), u_{1}=\left.u(x, t)\right|_{x=0}, u_{N}=\left.u(x, t)\right|_{x=l} ; \\
\frac{d i_{j}}{d t}=\frac{1}{L_{0}}\left(\frac{u_{j-1}+u_{j+1}}{2 \Delta x}-R_{0} i_{j}\right), \quad \frac{d u_{j}}{d t}=v_{j}, \quad j=1, . ., N,
\end{gathered}
$$

де $\Delta x$ - крок дискретизації диференціальних рівнянь із частинними похідними.

Якщо проаналізувати рівняння (7), побачимо, що для знаходження напруг першого та останнього $N$-го вузлів дискретизації необхідно знайти невідомі напруги у фіктивних вузлах $u_{0}$ та $u_{N+1}$. Задля зменшення обсягу статті не наводимо процедуру пошуку напруг фіктивних вузлів, ознайомитися з цією процедурою можна, наприклад, у праці [13]. Тоді:

$$
\begin{gathered}
u_{0}=\frac{2 \Delta x L_{0}}{3}\left[\frac{1}{L_{S 1}}\left(e_{S 1}-R_{S 1} i_{S 1}-u_{C V 1}\right)+\right. \\
+\left(\frac{\Delta x g_{0} R_{0}}{L_{0}}+\frac{2}{L_{0} \Delta x}-\frac{1}{L_{S 1}}-\frac{1}{L_{R L}}\right) u_{1}-\frac{1}{2 \Delta x L_{0}} u_{2}+ \\
\left.+\left(\frac{\Delta x\left(g_{0} L_{0}+C_{0} R_{0}\right)}{L_{0}}-\Delta x g_{0}\right) v_{1}+\frac{R_{0}}{L_{0}} i_{1}+\frac{R_{R L}}{L_{R L}} i_{R L}\right] .(9) \\
u_{N+1}=2 \Delta x L_{0}\left[\frac{1}{2 \Delta x L_{0}} u_{N-1}-R_{0} i_{N}-\right. \\
\left.-\frac{1}{L_{0} \Delta x}\left(u_{N}-\Delta x R_{0} i_{N}-u_{P}\right)\right] .
\end{gathered}
$$

Аналізуючи вираз (10), бачимо, що у нього входить напруга в кінці лінії (з боку системи 2) 3 правого боку лінії. Знайти цю напругу можемо, використовуючи вираз [13]:

$$
u_{P}=\frac{L_{0} \Delta x L_{R P} L_{S 2}}{L_{R P} L_{S 2}+L_{0} \Delta x\left(L_{R P}+L_{S 2}\right)}\left[\frac{1}{L_{0} \Delta x} u_{N}-\right.
$$

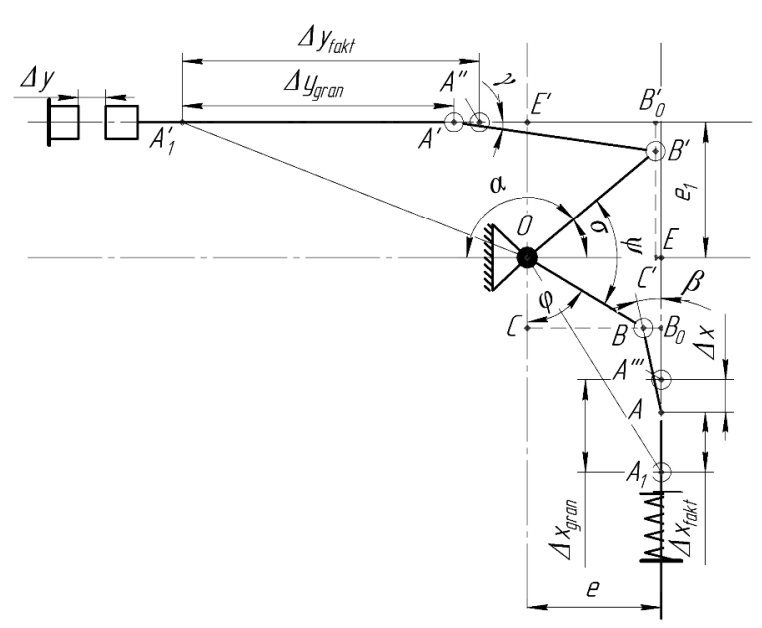

Рис. 2. Кінематичне схема кривошипношатунного механізму переміщення контактів елегазового вимикача LTB 362-800 (T) E4 


$$
\left.-\frac{R_{0}}{L_{0}} i_{N}+\frac{1}{L_{S 2}}\left(R_{S 2} i_{S 2}+e_{S 2}\right)+\frac{R_{R P}}{L_{R P}} i_{R P}\right] .
$$

На рис. 2 наведено кінематичну схему механізму переміщення контактів елегазового вимикача фірми $A B B$ типу $L T B 362-800(T) E 4$, розроблення та верифікацію математичної моделі якого ми здійснили в праці [9], тому наводимо лише остаточні рівняння, які описують механічний стан пристрою переміщення контактів вимикача і доповнюють рівняння (5):

$$
\begin{gathered}
\Delta y=\Delta y_{\text {fakt }}-\Delta y_{\text {gran }}, \Delta x_{\text {fakt }}=\Delta x_{\text {gran }}-\Delta x_{P} ; \\
\Delta y_{\text {fakt }}=\sqrt{\left(\left|O B^{\prime}\right|+\left|B^{\prime} A^{\prime}\right|\right)^{2}-e_{1}^{2}}-\left[\left|B^{\prime} A^{\prime}\right| \sqrt{1-\left[\frac{\left|O B^{\prime}\right| \sin \left((\varphi+\psi)-90^{\circ}\right)-e_{1}}{-\left|B^{\prime} A^{\prime}\right|}\right]^{2}}-\right. \\
\left.-\left|O B^{\prime}\right| \cos \left((\varphi+\psi)-90^{\circ}\right)\right] ; \\
\varphi=-250024 \Delta x_{\text {fakt }}^{6}+169265 \Delta x_{\text {fakt }}^{5}-45136 \Delta x_{\text {fakt }}^{4}+6044 \Delta x_{\text {fakt }}^{3}-427,4 \Delta x_{\text {fakt }}^{2}+22,78 \Delta x_{\text {fakt }}+0,6194,
\end{gathered}
$$

де $\Delta y_{f a k t}-$ відстань, що виникає після переміщення точки $A^{\prime}$ в точку $A^{\prime \prime}$, до розходження контактів $\Delta y_{\text {fakt }}=\Delta y_{\text {gran }}$.

Для апроксимації функції $r_{D}(\Delta y)$ ми використали інтерполяцію сплайнами третього порядку та отримали такі вирази [9]:

$$
\begin{gathered}
r_{D_{0 \div 0,01}}=0,1+21990 \Delta y_{0 \div 0,01} ; \\
r_{D_{0,01 \div 0,02}}=220+21990\left(\Delta y_{0,01 \div 0,02}-0,01\right)+8,01 \cdot 10^{7}\left(\Delta y_{0,01 \div 0,02}-0,01\right)^{3} ; \\
r_{D_{0,02 \div 0,07}}=520+46020\left(\Delta y_{0,02 \div 0,07}-0,02\right)+2,403 \cdot 10^{6}\left(\Delta y_{0,02 \div 0,07}-0,02\right)^{2}+ \\
3,6886 \cdot 10^{10}\left(\Delta y_{0,02 \div 0,07}-0,02\right)^{3} .
\end{gathered}
$$

Вирази (15)-(17) описують опір дуги на різних проміжках між контактами вимикача. Вираз (15) на проміжку $[0 ; 0,01]$ м, вираз $(16)-[0,01 ; 0,02]$ м та вираз $(17)-[0,02 ; 0,07]$ м. Тривалість горіння дуги вибрано згідно зі стандартами Міжнародної електротехнічної комісії.

Сумісному інтегруванню підлягає така система диференціальних рівнянь: (3), перше та друге рівняння в (4), (5), (7), (8) з урахуванням (9)-(17).

\section{Результати комп'ютерної симуляції}

Прийняті нижче параметри елементів заступної схеми на рис. 1 відповідають параметрам фрагмента реальної електричної мережі 750 кВ із лінією електропередачі завдовжки 476 км, яка 3’єднує ПС “Західноукраїнська” (Україна) з ПС “Альбертірша” (Угорщина). Параметри елементів такі: $e_{S 1}=612 \sin \left(\omega t+21,2^{\circ}\right) \mathrm{kB}, e_{S 2}=600 \sin \left(\omega t++0,57^{\circ}\right) \mathrm{\kappa B}, \omega=314 \mathrm{c}^{-1}=$ const, $R_{S 1}=2,01$ Ом, $R_{S 2}=2,3$ Ом, $L_{S 1}=0,158 \Gamma_{\mathrm{H},} L_{S 2}=0,138 \Gamma \mathrm{H}, R_{0}=1,9 \cdot 10^{-5}$ Ом $/ \mathrm{M}, L_{0}=9,24 \cdot 10^{-7} \Gamma \mathrm{H} / \mathrm{M}, C_{0}=1,3166 \cdot 10^{-11}$ $\Phi / \mathrm{M}, g_{0}=3,25 \cdot 10^{-11} \mathrm{CM} / \mathrm{M}, C_{V 1}=C_{V 2}=400 \cdot 10^{-12} \Phi, R_{R L}==R_{R P}=3,415$ Ом, $L_{R L}=L_{R P}=5,974$ Гн, $k=650000 \mathrm{H} /$ м (для пружини, яка працює на вимкнення), $k=180000 \mathrm{H} /$ м (для пружини, яка працює на ввімкнення), $m=10$ кг, $B O=0,13 \mathrm{~m}, A B=0,11 \mathrm{м}, e==0,13 \mathrm{м}, B^{\prime} O=0,6 \mathrm{M}, A^{\prime} B^{\prime}=0,2 \mathrm{м}$, $e_{1}=0,13 \mathrm{M}, \psi=86,5^{\circ}, \Delta x_{\text {gran }}=0,16 \mathrm{M}, \Delta y_{\text {gran }}=0,06 \mathrm{M}, F_{X}=0 \mathrm{H}, k_{d}=0 \mathrm{Hc} / \mathrm{M}$.

Комп'ютерну симуляцію здійснено для дослідження перехідних процесів у циклі однократного неуспішного АПВ під час стійкого КЗ у кінці лінії (точка $K$ на рис. 1 ) у такій послідовності. Спочатку впродовж 0,2 с був розрахований вихід системи на усталений режим 
Математичне моделювання комутаційних електромагнітних процесів у довгих лініях електропередач ...

передавання потужності із системи 1 у систему 2 за відсутності КЗ. У момент часу $t=0,2$ с виникло КЗ, а ще через час 0,043 с (час спрацювання релейного захисту плюс власний час вимкнення вимикача), тобто за $t=0,243 \mathrm{c}$, розпочалося розмикання контактів вимикача та вимкнення лінії. Після вимкнення вимикачем струму К3 $(t=0,264$ с) розпочався відлік часу для безструмової паузи (розглядаємо швидкодіючий вимикач, час безструмової паузи для якого згідно із циклом АПВ становить $0,3 \mathrm{c}$ ). У момент часу $t=0,564$ с розпочався процес повторного ввімкнення вимикача і його контакти почали замикатися (власний час увімкнення вимикача увійшов у час безструмової паузи). Через 0,02 с після початку процесу повторного ввімкнення вимикача релейний захист зреагував на стійке КЗ і розпочався відлік часу на його роботу $0,02 \mathrm{c}$ та часу власного вимкнення вимикача $0,02 \mathrm{c}$, а в момент часу $t=0,624$ с почалося повторне вимкнення лінії. Під час симуляції знехтувано як втратами енергії, так і коливними процесами у механізмі переміщення контактів вимикача.

На рис. 3 подано струм $i_{S 1}$ від системи 1, що протікає через вимикач. В нормальному усталеному режимі амплітуда цього струму становила 1,2 кА. Ударний струм під час КЗ сягнув значення 6,23 кА, а після неуспішного АПВ (ввімкнення вимикача на стійке КЗ у кінці лінії) вже за інших початкових умов - лише 3,7 кА, після чого відбулося остаточне вимкнення лінії.

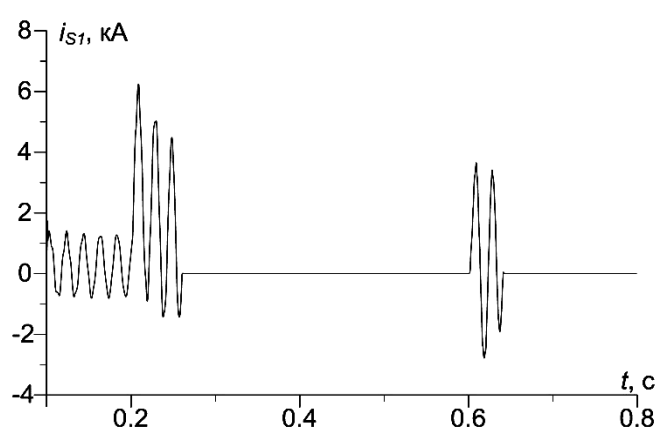

Рис. 3. Струм $i_{S 1}$ від системи 1 через вимикач

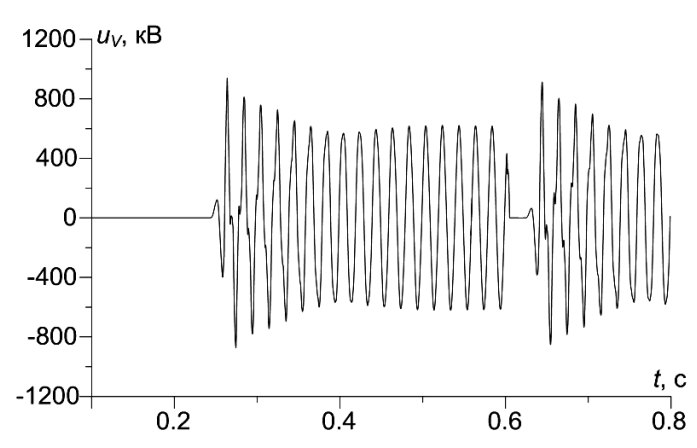

Рис. 4. Напруга між контактами вимикача

Перехідний процес зміни напруги між контактами вимикача показано на рис. 4. Бачимо, що після першого вимкнення найбільше значення перехідної відновної напруги становило 930 кВ, а коефіцієнт перевищення амплітуди $-K_{\mathrm{a}}=1,44$, із подальшим зменшенням цієї напруги під час безструмової паузи до напруги системи 1. Під час неуспішного АПВ вимикача 3 його прискореним повторним вимкненням характер перехідного процесу зміни напруги подібний до попереднього за дещо менших іiі значень.

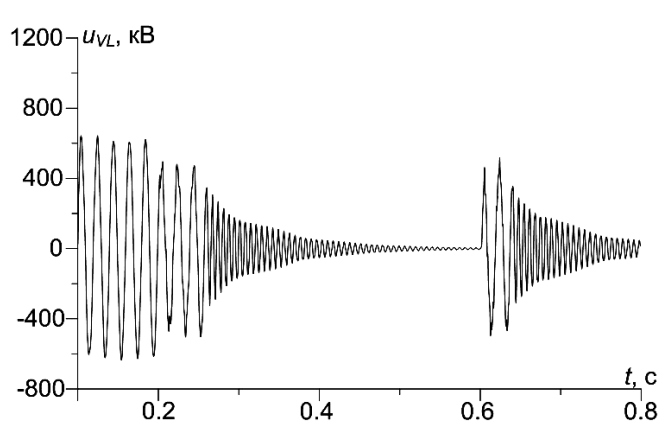

Рис. 5. Фазна напруга на вимикачі з бокулінії

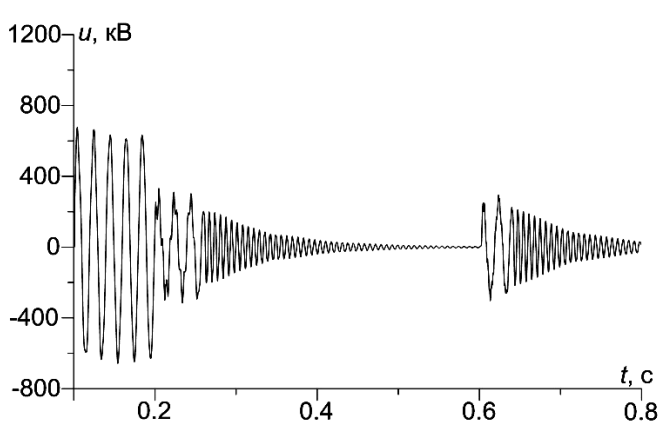

Рис. 6. Фазна напруга посередині лініі

На рис. 5 показано зміну фазної напруги на вимикачі з боку лінії. Аналізуючи рисунок, бачимо, що до КЗ значення амплітуди фазної напруги становило приблизно 610 кВ, що відповідало доаварійному 
нормальному усталеному режиму. Під час КЗ амплітуда цієї напруги зменшилася до 460 кВ, а після вимкнення лінії розпочався перехідний процес згасання вільних коливань із поступовим зменшенням цієї напруги до нуля. Після АПВ і другого вимкнення лінії спостерігається подібний характер перехідного процесу, як і під час першого.

На рис. 6 та 7 показано часові залежності фазної напруги та струму посередині лінії. Порівнюючи рис. 6 і рис. 5, бачимо, що характер зміни напруги посередині лінії практично повторює характер зміни напруги на ії початку за менших (особливо під час вимкнення вимикача) ії значень. Порівнюючи рис. 7 і рис. 3, бачимо, що характер зміни струму посередині лінії, коли увімкнено вимикач, фактично повторює характер зміни струму $i_{S 1}$ від системи 1 , а якщо вимкнено вимикач (під час безструмової паузи) - характер згасання вільних коливань подібний до зміни напруги 3 поступовим їх зменшенням до нуля.

Механічні процеси у вимикачі для досліджуваного однократного неуспішного АПВ лінії характеризуються поданою на рис. 8 часовою залежністю зміни відстані між контактами одного розриву вимикача під час їх переміщення. 3 рисунка бачимо, що закон зміни відстані нелінійний і за заданих параметрів вимикача тривалість переміщення контактів під час вимкнення становить $0,021 \mathrm{c}$, а під час ввімкнення - 0,043 c, що відповідає його робочим характеристикам.

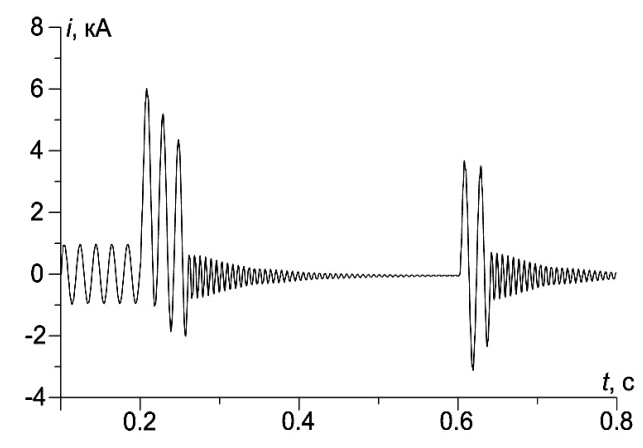

Рис. 7. Фазний струм посередині лінії

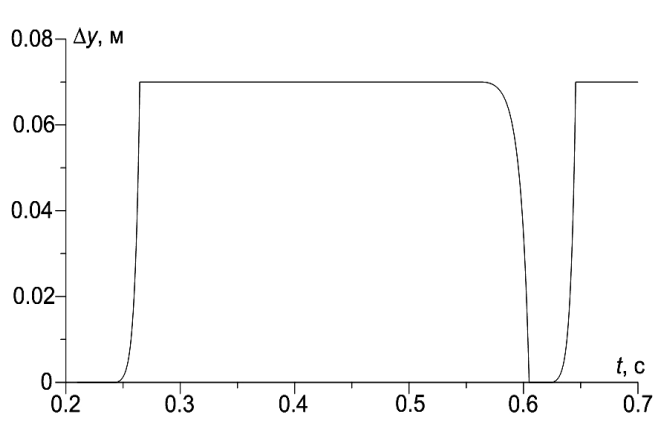

Рис. 8. Перемімення контакту одного розриву вимикача

\section{Висновки}

1. Використання модифікованого принципу Гамільтона-Остроградського, який грунтується на єдиному енергетичному підході, дає змогу будувати моделі електротехнічних та електромеханічних підсистем як елементів єдиної електроенергетичної системи, зокрема, математичну модель елегазового вимикача надвисокої напруги та інших елементів електричних мереж.

2. Запропонована в роботі методика ідентифікації крайових умов другого роду щодо диференціального рівняння довгої лінії дає змогу аналізувати перехідні процеси в елементах електричних мереж, не використовуючи еквівалент самої лінії у вигляді електричного кола. Такий підхід підвищує ефективність побудови моделі довгої лінії, оскільки не потребує створення розширених колових заступних схем, з одного боку, та дає змогу на польовому рівні врахувати перебіг електромагнітних процесів, 3 другого.

3. Використання математичної моделі вимикача надвисокої напруги дає змогу враховувати комутаційні дугові процеси на основі нелінійного активного опору та ємності й динаміку руху механізму переміщення контактів на основі теорії Лагранжа. Це уможливлює дослідження реальних перехідних процесів у електричних мережах без процедури пошуку початкових умов комутації.

Список використаних джерел

1. Голота А. Д. Автоматика в електроенергетичних системах / А. Д. Голота. К.: Вища школа, 2006. $367 c$. 
Математичне моделювання комутаційних електромагнітних процесів у довгих лініях електропередач ...

2. Руководство по эксплуатации выключателя LTB 362-800 (T) E4. ABB. 2009. 246 c.

3. Вишневский Ю.И.Электрические аппараты высокого напряжения с элегазовой изоляцией / Ю. И. Вишневский. - СПб. : Энергоатомиздат, 2002. 728 с.

4. Methods of Performance Assurance for SF6 Circuitbreakers at Switchings of Compensated 500-1150 kV Overhead Power Lines / Ivan Ye. Naumkin, Viktor N. Pod'yachev, Leonid I. Sarin, Danila V. Kochura. International Conference on Power Systems Transients (IPST2013) (July 18-20, 2013).

5. Probabilistic impact of transmission line switching on power system operating states / Payman Dehghanian, Mladen Kezunovic. Transmission and Distribution Conference and Exposition (T\&D2016) (2016 IEEE/PES).

6. An adaptive reclosure scheme for parallel transmission lines with shunt reactors / Da Lin, Huifang Wang, Shaofei Shen. Transmission and Distribution Conference and Exposition (T\&D2016) (2016 IEEE/PES).

7. Transients caused by uncontrolled and controlled switching of circuit breakers / Ivo Uglešic, Božidar Filipovic-Grcic and Srecko Bojic. The International Symposium on High-Voltage Technique "Höfler's Days". Portoroz, Slovenia. (7-8 November 2013).

8. Fault analysis on three phase system by auto reclosing mechanism / Vinesh Gamit, Vivek Karode, Karan Mistry, Pankaj Parmar, Ashish Chaudhari. International Journal of Research in Engineering and Technology. Vol. 04, Issue: 05, p. 292-298.

9. Моделювання вимикача надвисокої напруги для аналізу перехідних процесів в електротехнічних системах пересилання енергії / Левонюк В. Р., Лисяк Г. М., Чабан А. В. // Вісник Національного університету “Львівська політехніка”, Серія: “Електроенергетичні та електромеханічні системи”. 2018. № 900. C. $36-46$.

10. MayrO. Beitriige zur Theorie des statischen und des dynamischen Lichtbogens // Archiv fur Elektroteehnik. 1943. 37, Heft 12. S. 588-608.

11. Чабан А. В. Принции Гамільтона-Остроградського в електромеханічних системах / А. В. Чабан. Львів: В-во Тараса Сороки, 2015. 488 c.

12. Mathematical model of the double conductor power line usinf a modified Hamilton's principle / Andriy Czaban, Marek Lis, Jaroslaw Sosnowski, Witaliy Lewoniuk/Electric machines. 2016. № 109, pp. 31-36.

13. Mathematical modelling of transient processes in power supply grid with distributed parameters / Andriy Czaban, Marek Lis, Marcin Chrzan, Andrzej Szafraniec, Vitaliy Levoniuk. Przeglad elektrotechniczny. 2018. № 1, pp. $17-20$.

\section{References}

1. Holota, A. D. (2006). Avtomatyka v elektroenerhetychnykh systemakh [Automation in electric power systems]. Kyiv, 367 p. (ukr).

2. Rukovodstvo po ekspluatatsii vyiklyuchatelya LTB 362-800 (T) E4. [Manual for operating the switch LTB 362-800 (T) E4.] ABB. 2009. 246 p (rus).

3. Vishnevskiy, Yu. (2002). Elektricheskie apparatyi vyisokogo napryazheniya s elegazovoy izolyatsiey [Highvoltage electric devices with SF6 insulation]. Sankt-Peterburg, 728 p.(rus).

4. Methods of Performance Assurance for SF6 Circuitbreakers at Switchings of Compensated 500-1150 kV Overhead Power Lines / Ivan Ye. Naumkin, Viktor N. Pod'yachev, Leonid I. Sarin, Danila V. Kochura. International Conference on Power Systems Transients (IPST2013) (July 18-20, 2013).

5. Probabilistic impact of transmission line switching on power system operating states / Payman Dehghanian, Mladen Kezunovic. Transmission and Distribution Conference and Exposition (T\&D2016) (2016 IEEE/PES).

6. An adaptive reclosure scheme for parallel transmission lines with shunt reactors / Da Lin, Huifang Wang, Shaofei Shen. Transmission and Distribution Conference and Exposition (T\&D2016) (2016 IEEE/PES).

7. Transients caused by uncontrolled and controlled switching of circuit breakers / Ivo Uglešic, Božidar Filipovic-Grcic and Srecko Bojic. The International Symposium on High-Voltage Technique "Höfler's Days". Portoroz, Slovenia (7-8 November 2013).

8. Fault analysis on three phase system by auto reclosing mechanism / Vinesh Gamit, Vivek Karode, Karan Mistry, Pankaj Parmar, Ashish Chaudhari. International Journal of Research in Engineering and Technology. Vol.: 04 Issue: 05, pp. 292-298. 
9. Levoniuk, V. R., Lysiak, H. M., Chaban, A. V. (2018). Modeliuvannia vymykacha nadvysokoi napruhy dlia analizu perekhidnykh protsesiv $v$ elektrotekhnichnykh systemakh peresylannia enerhii [Simulation of a super-high voltage switch for the analysis of transients in electrical energy transfer systems]. Bulletin of the Lviv Polytechnic National University, Series: "Electric Power and Electromechanical Systems". No. 900. pp. 36-46.

10. Mayr O. Beitriige zur Theorie des statischen und des dynamischen Lichtbogens / O. Mayr // Archiv fur Elektroteehnik. 1943. 37, Heft 12. S. 588-608.

11. Chaban, A. (2015). Pryntsyp Hamiltona-Ostrohradskoho $v$ elektromekhanichnykh systemakh [The principle of Hamilton-Ostrogradsky in electromechanical systems]. Lviv, 488 p. (ukr).

12. Mathematical model of the double conductor power line usinf a modified Hamilton's principle / Andriy Czaban, Marek Lis, Jaroslaw Sosnowski, Witaliy Lewoniuk / Electric machines. 2016. No. 109, pp. 31-36.

13. Mathematical modelling of transient processes in power supply grid with distributed parameters / Andriy Czaban, Marek Lis, Marcin Chrzan, Andrzej Szafraniec, Vitaliy Levoniuk. Przeglad elektrotechniczny. 2018. No. 1, pp. 17-20.

\author{
A. V. Chaban \\ Lviv Polytechnic National University, \\ Department of Electrical Engineering Systems, \\ e-mails: atchaban@gmail.com,
} H. M. Lysiak
Lviv Polytechnic National University,
Department of Electric Power Engineering and Control Systems
e-mail: gmlysiak@gmail.com

V. R. Levoniuk

Lviv Polytechnic National University, Department of Electrical Engineering Systems, e-mail: gmlysiak@gmail.com

\title{
MATHEMATICAL MODELING SWITCHING ELECTROMAGNETIC PROCESSES IN THE LONG POWER LINE IN THE AUTOMATIC RECLOSING CYCLE
}

(C) Chaban A. V., Lysiak H. M., Levoniuk V. R., 2019

The article analyzes scientific publications, who showed that for the most part, the study of switching transients in electrical networks during automatic reclosing cycles of circuit breaker, are carried out without taking into account the influence of electromechanical processes in the mechanisms of circuit breaker contacts, despite the fact that the speed of their course is commensurate with the speed of the electromagnetic processes. On the basis of the modified Hamilton-Ostrogradsky principle proposed mathematical model of a fragment of an electric network which consists of an inter-system overhead power line compensating reactors and a high-voltage circuit breaker with the device automatic reclosing cycle.

It is shown that the proposed method of identification of boundary conditions of the second kind to the differential equation of a long line increases the efficiency of constructing its model, since it does not require the creation of extended circular alternatives on the one hand; and allows the field level to take into account the flow of electromagnetic processes from the second. The mathematical model of the high-voltage switch used in the work makes it possible to take into account switching arc processes based on nonlinear active resistance and capacitance and motion dynamics of the mechanism of contact movement based on Lagrange theory. This makes it possible to efficiently investigate the transients in the electrical networks during the switching circuit breakers without using the initial switching 
Математичне моделювання комутаційних електромагнітних процесів у довгих лініях електропередач ...

procedure. On the basis of the developed mathematical model written software code in the algorithmic language Visual Fortran and done computer simulation of transient switching processes in a long transmission line, taking into account the operation of a single-unit automatic reclosing cycle and mechanical processes in the circuit breaker. The research results are presented in the form of drawings that are analyzed.

It is confirmed that the development and application of interdisciplinary (interdisciplinary) research methods makes it possible to build models of electrotechnical and electromechanical subsystems as elements of a single power system, including mathematical models of ultra-high-voltage switches, based solely on a single energy approach.

Key words: mathematical modeling, switching processes, Hamilton-Ostrogradsky principle, electric network, high-voltage circuit breaker, automatic reclosing cycle 